\title{
The role proximity plays in university-driven social networks. The case of the US and EU life-science clusters
}

\author{
Małgorzata Runiewicz-Wardyn ${ }^{1}$
}

\begin{abstract}
Over the last decade, the research in the field of technology and innovation has progressed towards the development of the notion of an 'ecosystem' that lays within the idea that innovation and technological advances stem from collective research efforts and social interactions. The paper delivers new insights on successful universitybased innovation ecosystems, by exploring the role of proximities in university-driven social networks. Two research problems are discussed: $1 /$ the structure and dynamics of university-driven social networks, and 2/the role of proximities as pre-conditions for stronger social ties and more frequent interactions. The author applies a qualitative interview and direct observation methods on the example of several selected lifescience university-based ecosystems in the EU and the US. The study identifies several fundamental relationships: (1) the presence of high physical, cognitive and organizational proximities within university-based ecosystems contributes to social networking and the interchange of knowledge; (2) cognitive and organizational proximities are the primary motives for social collaborations within universitybased ecosystems; (3) physical proximity matters most when strong social networks already exist; (4) physical proximity allows ecosystem players to have more informal interactions; (5) cultural and social proximities increase more effective communication, trust and knowledge sharing; (6) social networking within university-based ecosystems may be partially engineered by the brokerage function of intermediary organizations and managers, aiming to narrow organizational, technological and cognitive proximities between ecosystem players. Bridging organizational, cognitive and social distances must be one of the regional innovation policies priorities. Further research must consider increasing technological convergence, shortening technological cycles and globalization processes within the life-science sector.
\end{abstract}

Keywords: proximity, social networks, innovation ecosystem, life science, university

1 Małgorzata Runiewicz-Wardyn, Ph.D., Kozminski University, ul. Jagiellońska 57/59, 03-301 Warsaw, e-mail: mruniewi@alk.edu.pl (ORCID ID: 0000-0002-0468-3705).

Received 27 April 2019; Revised 24 June 2019, 2 September 2019; Accepted 3 October 2019 


\section{INTRODUCTION}

The Triple Helix (TH) (university-industry-government interlinkages) approach to 'innovation systems' has been widely accepted, especially in the public sector. Recently, however, there has been an attempt to enrich this approach with the new concept of the Quadruple Helix $(\mathrm{QH})$. This is grounded in the idea that innovation is the outcome of an interactive and trans-disciplinary process involving "all stakeholders as active players in jointly creating and experimenting in the new ways of doing things and creating new services and products" (European Commission, 2015). Notably, the QH approach builds on the emerging concept of an 'innovation ecosystem' and widens the TH concept with one more helix - society and societal perspective (McAdam \& Debackere, 2018; Carayannis \& Campbell, 2012). Consequently, in the QH interactions, knowledge transfer among innovation actors is additionally strengthened by social, trust-based relations among actors or so called "social proximity". The concept of an 'innovation ecosystem' refers to a network of interconnected organizations, connected to a focal firm or a platform, that incorporates both production and user side participants, and creates and appropriates new value through innovation (Autio \& Thomas, 2014).

The interest in social networks within the aforementioned innovation ecosystems and their role in sharing knowledge and ideas, as well as stimulating inventions and innovations, have been progressively discussed. Several literature sources mention the concept of a 'university-based innovation ecosystem', which lies within the idea of the QH networks of innovation ecosystem. This refers to a university as an 'attractor' for developing and transferring innovative ideas via the social interactions between students, faculty, companies, intermediary agents, investors, and local authority representatives (Broekel \& Boschma, 2016; Ponds, Oort, \& Frenken, 2009; Audretsch \& Feldman, 2004; Audretsch \& Stephan, 1996; Adams, 2002; Anselin et al., 1997; Golejewska, 2018). These studies emphasize the importance of various types of "proximities" for the interactions and exchange of knowledge and innovations. The term proximity refers here to the degree to which one element is close to another. In this sense, proximity facilitates the interaction of actors with complementary pieces of knowledge, skills, and experiences. One popular type of proximity is the geographical dimension of proximity, such as the physical closeness of two or more actors. For example, studies by Fitjar et al. (2016) and Lorenzen (2007) show that geographical proximity between university ecosystem actors provides opportunities for frequent, interpersonal contacts, allowing the reduction of information asymmetries, whereas organizational and cultural proximities have an impact on the evolution of social interactions and social capital formation. 
Unfortunately, other types of proximities, including cognitive, social and institutional proximities, have been largely neglected in the subject literature. Moreover, most of the existing subject literature on 'open innovation ecosystems' and QH linkages is grounded in the context of firms. Only a few studies consider social networks in the context of universities. In the recent studies by Schiumi and Carlucci (2018) and Fransman (2018), the authors emphasise the importance of universities (with their specialized knowledge, ideas, and skills) for companies' research and development, as well as the role of social interactions among the ecosystem players in facilitating knowledge flows. At the same, the authors do not provide more evidence on what factors influence such interaction.

After reviewing the existing state-of-the-art literature, the researcher seeks to fill the above mentioned literature gap by bringing new evidence to the role of physical, cognitive, cultural, institutional and technological proximities for university-driven social network formations. The paper aims at contributing to the emerging debate on the role of proximity (different types of proximities) in the research collaboration and social networking within university-based innovation ecosystems. More specifically, it aims to answer what role one or more dimensions of proximity play in strengthening $\mathrm{QH}$ interlinkages in the selected university-based ecosystems and, therefore, provide better conditions for the innovation process to take place. The concept of a 'university-based ecosystem' is defined as a complex set of relationships among actors from universities and research institutes, enterprises, and other institutions, that lead to the inter-exchange of technology and information, and stimulate innovations. In order to achieve the research aim, the author takes the example of three different life-science university ecosystems and discusses two major research problems: $1 /$ the structure of the analyzed university-driven social networks; 2 / the role of proximities - geographical, cognitive, technological, social, institutional and cultural - as pre-conditions for stronger interpersonal ties and more frequent interactions.

The following study provides new insights into the functioning of university-based ecosystems, and the role of social networks within the Triple (Quadruple) Helix model. The results of these insights enable the development of strategies and policy measures that further unlock the innovation potential in the universities and their local communities.

The paper is divided into seven sections. The introduction is followed by a presentation of the theoretical framework of the research study. The types of proximities, social networks ties, and their configurations are discussed here. Next, three sections discuss the technological convergence and research collaboration within the life-science sector as well as the role of university-based ecosystems in such collaboration. Finally, the fifth section 
discusses the author's qualitative research findings. The paper ends with the research conclusions and implication for the further studies.

\section{LITERATURE REVIEW}

The theoretical concept behind the university-driven social networks originates from the theory of the innovation ecosystem and the TH theory. $\mathrm{QH}$ is not a very well established and widely used concept in innovation research and in innovation policy. Three elements, which are important for the following research, are common to both analytical models ( $\mathrm{TH}$ and $\mathrm{QH}$ ). The first is the institutional element, covering actors from university, industry and government sectors. The second is the relational element, involving the relationships between all the mentioned actors, which include collaboration, moderation, leadership, substitution and networking. The third is the functional element, described as processes taking place in what Etzkowitz (2008) calls "Knowledge, Innovation and Consensus Spaces".

Furthermore, over the last two decades a significant body of Triple (Quadruple) Helix theoretical and empirical research has been developed along two main complementary perspectives: a (neo)institutional one and a (neo)evolutionary one. The first one examines various Triple (Quadruple) Helix configurations and induces mechanisms in national and regional contexts (e.g. Etzkowitz, Mello \& Almeida, 2005; Saad \& Zawdie, 2011; González-López, 2014). The second one looks at university, industry and government as co-evolving sub-sets of social systems that interact through market selections, innovative dynamics, network controls, and communicate through specific codes (Etzkowitz \& Leydesdorff, 1995).

The enhanced role of the university in the local innovation ecosystems arises from several specific developments in the subject literature. Firstly, the founder of the Triple Helix model, Etzkowitz (2003), has dedicated the university the 'third mission' - involvement in socio-economic development, next to the traditional academic missions of teaching and research. This, on the other hand, explains the stronger government interest in policies strengthening the links between universities, local community and the rest of society. Thus, universities and their social environments are the key players in the technological, social and economic development of regions. They serve as intermediaries between scientific knowledge and markets, and in such way promote the diffusion of innovations and foster competitiveness (see the works of Huggins et al., 2019; Johnston \& Huggins, 2017; Kim, 2013; Hughes \& Kitson, 2012; Garnsey \& Heffernan, 2010; Chapple et al., 2005; Feldman, 1999; Kenney, 2000). What is more, universities, unlike industries, are 
characterized by open knowledge creation and dissemination environments, whereas companies limit the access to their produced knowledge. As a result, universities and their ecosystems are considered a natural environment for local knowledge spillovers. The term 'ecosystem' alludes here to the biological sense of the ecosystem. One could find several different types of ecosystem in the subject literature: business ecosystem, innovation ecosystem, technology ecosystem, entrepreneurial ecosystem, etc. The heterogeneity of participants of the ecosystem models is of particular importance and difficulty when considering ecosystem boundaries. Indeed, ecosystems are dynamic communities who share complementary technologies and skills. The content of the social ties (both formal and informal) between actors within the ecosystems is different depending on the types of actors involved and the exchange of information and knowledge between them. As already stated before, this paper studies what role proximity has on social networks formation within university-based innovation ecosystems. Proximity does not create innovation, but only serves as an enabling factor for it to happen. As stated by Boschma (2005), there are several types of proximities facilitating these social ties and interactions, as well as an exchange of knowledge and information within an ecosystem, such as a geographical, cognitive and technological, social, cultural, organizational, and institutional one. The following section discusses each type of proximity in more details.

\section{Geographical proximity}

The geographical proximity appears as a distinctive element that leads to a clustering effect, especially useful for the transfer of tacit knowledge (Audretsch \& Stephan, 1996). The increasing role of geographical proximity in shaping economic and social interactions (labor mobility, inter-firm linkages, etc.), knowledge spillovers, and innovative propensity, has triggered the "new" economic geography literature. As Glaeser et al. (1992, p. 1126) observe, "intellectual breakthroughs must cross hallways and streets more easily than oceans and continents". Thus, knowledge spreads more rapidly in agglomerated urban areas and in close proximity to major universities. The role of university collaboration networks in geographically mediated knowledge spillovers has been emphasized and evidenced by a number of studies conducted by Anselin et al. (1997), Bania et al. (1993), Baptista (2001), Adams (2002), Trajtenberg et al. (1997), and Ponds, Oort, and Frenken (2009). Interactive, huge, and diverse social capital makes large agglomeration regions with proximity to academic institutions ideal locations for social networking events and knowledge exchange. 


\section{Cognitive and technological proximities}

A relatively small number of researchers have investigated the role of cognitive proximities and technological relatedness in the knowledge spillovers. Some names include the works of Petruzzelli (2011), Nooteboom (2000), Nahapiet and Ghoshal (1998), Brockhoff and Teichert (1995). In their findings, cognitive proximity is manifested by the homogeneity of competencies, capabilities and skills as well as the homogeneity of knowledge bases (Nooteboom, 2000, p. 3-11). The first level of homogeneity refers to cognitive similarity between individuals: communication codes, written specific technical language, common professional or scientific backgrounds. Whereas the second level of homogeneity refers to the cognitive similarity between independent organizations (in their knowledge bases, capabilities, competences, and experiences). Having an overlapping knowledge base and a shared technical vocabulary enhances the actors' ability to communicate and exchange information (Nahapiet \& Ghoshal, 1998). The existence of a shared language and codes leads to the creation of social capital - as Adler and Kwon (2000) put it, "social capital is unlikely to arise among people who do not understand each other" (p. 99). In relation to partners' technological relatedness, Petruzzelli (2011) suggests that in order to increase innovative performance, a certain threshold of similar technological competencies between partners is required. However, too much similarity may in turn have a detrimental effect on the actors' innovative performance since the development of valuable innovations may require dissimilar but also complementary sources of knowledge.

\section{Social proximity}

This concept of "social proximity" originates from the literature on embeddedness. It claims that economic behaviour is heavily embedded in social relations, in which behavioural factors such as trust, openness, professionalism, complementarity and transparency are of key importance. The trustful relations among actors, driven by friendships or common experiences, encourage further development of new networks and the exchange of tacit-knowledge between related actors (Maskell \& Mallberg, 1999; Ziemiański, 2018). Based on her study results, Feldman (1999) argues that decisions of the faculty members to start a company are socially conditioned, e.g. "efforts by pioneering faculty members to start a company lead other faculty members to found companies as well". It is in fact defined in terms of "socially embedded relations between agents at the micro-level" (Boschma, 2005). Therefore, common friendships and experiences among actors guarantee trust-based relations among actors and thus it strengthens 
social proximity. These trust-based relationships also help build an open attitude of "communicative rationality" (Lundvall, 1993), rather than a purely market-oriented narrow communication.

\section{Cultural proximity}

Norms are unwritten social and cultural rules for how people should behave in various social relations and contexts. Research show that shared norms and beliefs in networks and social relations play an important role in the creation of social capital (Adler \& Kwon, 2000). Furthermore, Nahapiet and Ghoshal (1998) state that norms represent a degree of consensus in a social system and that 'norms of cooperation' may influence the creation of social capital. These norms have influence on people's attitudes and motivations towards social interactions and social exchange, which, on the other hand, affect the social capital embedded within a network. Culture affects how people perceive and interpret their environment. The latter implies that individuals sharing a common language and culture are more likely to perceive the social interactions and exchanges in similar ways. For example, a culture of shared trust and similar habits can make knowledge transfer easier and people more willing to exchange information.

\section{Institutional proximity}

Institutional proximity refers to the interaction among actors from various institutions within the Triple Helix spheres. Much of the Triple (Quadruple) Helix literature focuses on the institutional spheres of university, industry and government in a holistic way, without going deeper to the specific actors within each sphere, their institutional identities, objectives and social interaction dynamics. As Jensen and Tragardh (2004) put it, cooperation within the Triple (Quadruple) Helix model is complex, dynamic and ambiguous, thus the institutional architecture of particular Triple (Quadruple) Helix relationship models may differ by sector, e.g. in the case of aerospace the government would occupy a larger role than in life sciences. Furthermore, geographical proximity can facilitate collaboration between the institutions, however, social interactions and trust can smoothen and make these interactions successful.

\section{Organizational proximity}

The literature on the organizational dimension of proximity identifies two levels of its analysis: the inter-organizational and the intra-organizational (Antonelli, 2000). The latter division results from the fact that knowledge 
spills over from one to another organization, but also among different units within the same organization. People are simultaneously proximate to everyone else in their organization, as they move about the organization. The latter facilitates interaction both intentional and accidental. The interorganizational proximity can be further distinguished from the low (loosely coupled) networks and weak ties between autonomous organization, to the highly networked, such as ownership and wholly-owned subsidiaries. In terms of the intra-organizational level, strong ties among different units define high organizational proximity, whereas weak ties correspond to a low proximity. Yet, in order to understand further the role of organizational proximity, different dimensions of organizational distance must be considered, each of which affect communication, friendships and social networking (Monge et al., 1985).

\section{Social network ties and configurations}

Granovetter (1973) distinguishes between strong and weak ties and states that the strength of a social tie is defined by a combination of the time invested, the emotional intensity, the intimacy or mutual confiding between the actors. In other words, ties with a higher degree of emotional involvement, are more important in the discovery of a business opportunity and weak ties become more important when exploiting these opportunities. Furthermore, Coleman (1988) argues that networks with a closed structure are better at facilitating social capital, as demonstrated in Figure 1 (a), than social networks characterized by an open structure, which is illustrated by Figure 1 (b).

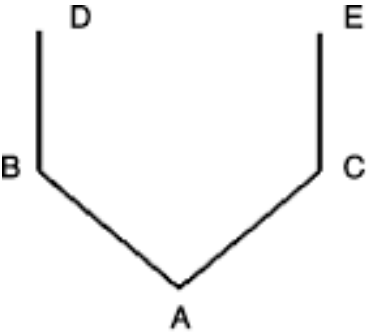

(a)
B

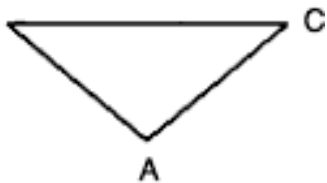

(b)

Figure 1. Social network without and with "closure"

Source: Coleman (1988). 
Burt (1992), who introduced the concept of structural hole in networks, argues, on the contrary, that low density and connectivity are the most beneficial features of a social network. Structural holes mean that an individual has persons in his or her network that do not know each other and is defined as "a relationship of non-redundancy between two contacts", which is illustrated by the hole between contacts in a network that do not have any relationship to each other. In this way, that person is more likely to have access to socalled non-redundant information, i.e. information that is fresher and unique. Furthermore, Coleman (1988) argues that most social capital networks with closure create larger social capital while Burt (1992), on the other hand, argues that structural holes, i.e. without closure are the most beneficial network configuration in this study. In the start-up phase, an entrepreneur might need both of these models of networks. First, a closed network could provide trust and emotional support, which might be very important when deciding whether to exploit a research or business idea. Second, structural holes might be important in order to create a competitive new venture.

\section{University-driven social networks}

In university-based ecosystems, a network of formal relationships among organizations and their actors merges with the personal network(s) that every individual has in the ecosystem. Feldman (1999) in her studies demonstrates that, for example, the decisions of "academics to start a business were socially conditioned". This suggests that physical proximity might not be enough to create the 'contagion effect' for the local university-based ecosystem players and the occasions for learning and knowledge exchange seem to be facilitated by a high level of embeddedness of their social relations with other actors. This is in contrary to Boschma (2005), who has evidenced that social networks are location specific, suggesting that knowledge spillovers are geographically localized as well. Furthermore, the seminal study by Powell et al. (1996) on social network structures and innovation in the life-science sector found that the nature of previous ties was an indicator of positional strength in these networks. Similarly, Burt (1992) argues that structural holes in the form of the connection gaps within networks are a matter of the relations existing between actors, rather than the 'physical' attributes of actors. Notwithstanding, studies by Gordon and McCann (2000), point out the risk of "too much social proximity", which means that people only relate to those with whom they are socially proximate. Nonetheless, a university-based ecosystem can provide opportunities and mechanisms that help contrast this possibility. Unfortunately, there are few studies that have applied the social network concept in an empirical manner with regard to examining links 
between universities, industry, local authorities and other related institutions within the local life-science ecosystem (Vonortas, 2009; Tortoriello, 2015; Kim et al., 2018). The following paper is one of the few attempts to contribute to the above-mentioned discussion on the role of physical, social and other types of proximities in the formation of university-driven social networks.

\section{Technological convergence and collaboration within the life-science sector}

Based on the theory of the innovation life cycle, the process of technological change in the life-science industry represents technological evolutions in the biopharmaceutical industry, as a whole. The life-science industry, including biotechnology, is a relatively young branch of bioscience, developed by the biopharmaceutical industry in the late 2000s. The innovation process shows that there is not one S-curve but a succession of S-curves from organic chemistry/pharmacology to biochemistry and molecular biology (Figure 2). It can be seen that the waves of molecular biology overlap the waves of biochemistry and are about to leap upwards. Currently, scientists and researchers are attempting to exploit basic molecular research to identify new drugs, the production of which is based on recent advances in genomics technology. Scientific breakthroughs such as genetic engineering, the ability to create monoclonal antibodies, and the mapping of the human genome have opened up new areas of research, and the pace of discovery in basic biomedical science has accelerated dramatically over the past few decades. These scientific trends, along with the dynamic growth of biopharmaceutical industry, require a convergent and a multi-disciplinary approach (applying a mix of knowledge from the biological sciences, chemical engineering, bioprocess engineering, information technology, and biorobotics) to produce new technological discoveries. The latter, on the other hand, brings the actors of the university ecosystems closer.

Furthermore, increasing competition drives the specialization and increases the role of business alliances and partnerships in research and innovation. The research results provided by Evald et al. (2006) emphasize the importance of strong social ties at the start-up phase of life-science sector companies as well as bridging the gap between biological and chemical sciences (Figure 2), which further accelerate the dynamics in life science. Furthermore, close collaboration is also important in the development of genomics technologies that requires massive amounts of information to be collected and analyzed, whereas the characterization of genes requires a means to manage, store and process enormous databases of biological information (bioinformatics). 


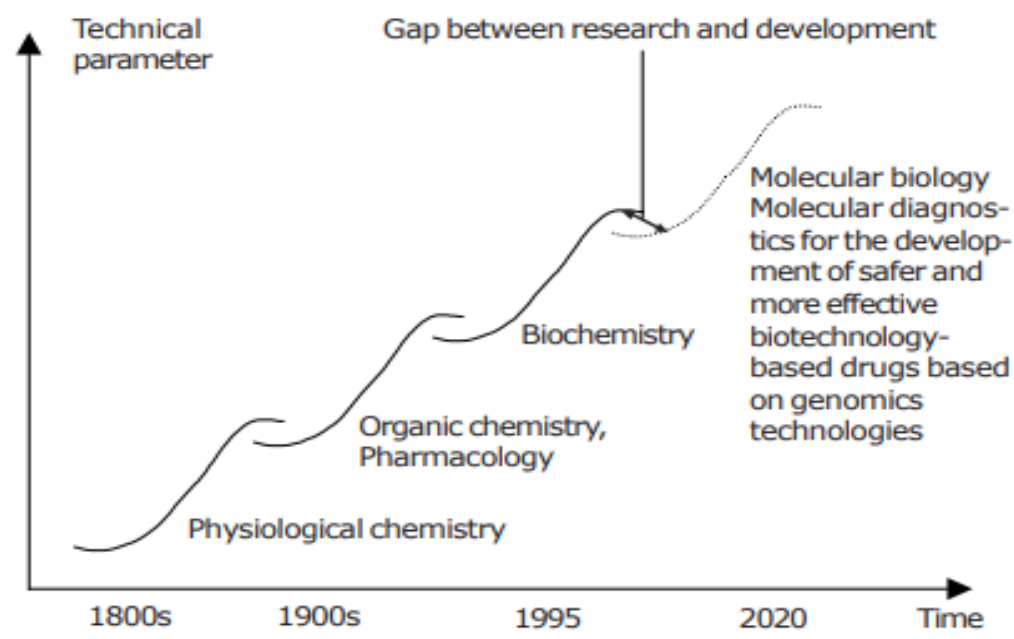

Figure 2. Technological change and technological convergence in the life-science industry

Source: own elaboration based on Utterback\&Abernathy (1975), and Fisher\&Pry (1971).

In sum, the technological convergence in life science, including the increasing role of bioinformatics, signifies the importance of the close integration of research efforts and social collaboration among the Triple Helix actors (pharmaceutical firms, intermediary institutions, hospitals, various university departments, etc.) of university-based ecosystems.

\section{RESEARCH METHODS}

In order to understand the role of proximity in university-driven social networks the author applied both quantitative and qualitative research methods. The qualitative research and the direct observations in the selected life-science university-based ecosystems in the European Union (EU) and the United States (US) were conducted in Copenhagen (Denmark), Lund (Sweden), Cambridge (UK) and the Bay Area (Palo Alto, San Jose, Fremont) (US) in July and August 2018. The 'interview' technique was applied in order to collect indepth content. The broad goal of the interviews was to gain knowledge and insights on how a university-based ecosystem fosters research collaboration and innovations, as well as to determine the role proximity plays in socialdriven networks formation within university-based innovation ecosystems. To proceed with this assignment, the researcher, firstly, identified a relevant common base to analyze and compare among the three life-science cluster 
ecosystems and, secondly, discussed the role of different types of proximities in the social-related activities of ecosystems' actors. This method allowed a better understanding of the complex nature of university-based innovation ecosystems and the process of social networking within it. The questionnaire contained mixed questions (open and closed) and was composed of four parts: (1) the mission, structure and types of social networks; (2) the methods of networking and intensity of interactions; (3) the role of different types of proximities in social networking; (4) the impact of social networks on R\&D collaboration and innovative performance.

The author conducted 47 interviews with the Heads and Deans of departments, the Technology Transfer Offices (TTO), related educational institutions and companies in the following life-science cluster ecosystems: Bay Area (Stanford University, Stanford Medical School and smaller local colleges: Ohlone College and Solano College), Medicon Valley (Copenhagen University, Lund University), Cambridge (Cambridge University, Cambridge Medical School, Trinity College). The number of interviews and average time per interview in each life-science cluster ecosystem is indicated in Table 1.

Table 1. Number of interviews and average time per interview

\begin{tabular}{llll}
\hline UE* & Bay Area & Medicon Valley & Cambridge \\
\hline $\begin{array}{l}\text { Number of } \\
\text { interviewees }\end{array}$ & 22 & 12 & 13 \\
$\begin{array}{l}\text { Total time of } \\
\text { interviews }\end{array}$ & $\begin{array}{l}10 \text { hours } 33 \\
\text { minutes }\end{array}$ & $\begin{array}{l}5 \text { hours } 30 \\
\text { minutes }\end{array}$ & 6 hours \\
$\begin{array}{l}\text { Average time of } \\
\text { interviews }\end{array}$ & 32 minutes & 44 minutes & 35 minutes \\
$\begin{array}{l}\text { Note: }{ }^{*} \text { UE university-based ecosystem. } \\
\text { *UE university-based ecosystem. }\end{array}$ & &
\end{tabular}

The list of all interviewed organizations is enclosed at the end of the paper. In order to analyze the evidence gathered, a multistep thematic content approach was applied. The researcher transcribed the interviews to gain preliminary results, and then looked for common and different patterns for all the analyzed ecosystems. Once common themes began to emerge, the researcher cross-referenced them with the existing literature. 


\section{EMPIRICAL ANALYSIS}

The drivers, structure and role of proximities in university-driven social networks depends on the stage of maturity, degree of internationalization and research excellence of the particular university ecosystem. All analyzed university ecosystems - Cambridge in the UK, Bay Area in the US, and Medicon Valley in the EU - have their own internal technological and social dynamics. Considering the intensity and scale of technology transfer activities (patents, start-ups, collaboration agreements and innovation-technology disclosers), two major types of clusters emerge - the world-class cluster and a mature cluster (Christensen et al., 2012). According to the European Cluster Observatory 2016 and the latest ranking by the Genetic Engineering \& Biotechnology News (GEN), Medicon Valley is 9th and 10th in the list of top biopharmaceutical clusters in the EU. This is surpassed by the Golden Triangle of CambridgeOxford-London, which (along with the US Bay Area life-science cluster) is now considered as a world-class leading biotechnology and life-science cluster. Table 2 presents a comparison of the three university-based innovation ecosystems considering their major universities rank, research excellence, human capital, internationalization and overall academic reputation.

The UK-based, Cambridge University ecosystem is one of the oldest and most successful ecosystems in the world, focused around one of the top academic and research institutions in the life-science sector. As after QS 2018 World University Ranking in Life Sciences, Cambridge University stays high in the expert opinions regarding teaching and research quality, number of citations per faculty and employer reputation (Table 2). It has a high market share of key innovations, top worldwide scientists, including Nobel Prize winners.

Similarly, the Bay Area life-science ecosystem has evolved around worldclass universities, such as Stanford University and University of California in Berkeley, which offer high-skilled talents and a very entrepreneurial and innovative culture. Stanford University has high teaching and research quality, which is also depicted in a high perception of students of teaching quality, high teacher/student ratios and valuable education for the worldwide employment market. Both Cambridge and Stanford Universities rank high in terms of attracting faculty and students from across the world, providing a multinational and diverse environment, facilitating exchange of best practices and beliefs. In fact, since the creation of Stanford University and other local universities in the Bay Area, the cluster has taken the lead in the establishment of university-industry collaborations, resulting in cutting-edge developments and inventions with a markedly practical application, which in turn, attracts more talent, firms, and investments (Table 2). 
Table 2. Levels of maturity, internationalization and excellence in Cambridge, Bay Area and Medicon Valley life-science ecosystems

\begin{tabular}{|c|c|c|c|c|}
\hline $\begin{array}{l}\text { Major } \\
\text { universities }\end{array}$ & $\begin{array}{l}\text { Cambridge } \\
\text { University }\end{array}$ & $\begin{array}{l}\text { Stanford } \\
\text { University }\end{array}$ & $\begin{array}{l}\text { Copenhagen } \\
\text { University }\end{array}$ & $\begin{array}{l}\text { Lund } \\
\text { University }\end{array}$ \\
\hline & \multicolumn{2}{|c|}{ World-class clusters } & \multicolumn{2}{|c|}{ Mature clusters } \\
\hline $\begin{array}{l}\text { Overall Score (average } \\
2018 / 2019 \text { ) }\end{array}$ & 95.6 & 98.6 & 63.5 & 62.1 \\
\hline Academic Reputation & 100 & 100 & 67.2 & 67.2 \\
\hline International Students & 97.7 & 70.5 & 28.0 & 71.8 \\
\hline $\begin{array}{l}\text { Market Share of Key } \\
\text { Innovations }\end{array}$ & significant & significant & growing & growing \\
\hline Citations per Faculty & 77.2 & 99 & 28.8 & 51.2 \\
\hline Employer Reputation & 100 & 100 & 47.0 & 52.6 \\
\hline Human capital & $\begin{array}{l}\text { worldwide } \\
\text { scientists, } \\
\text { (Nobel Prize } \\
\text { winners) }\end{array}$ & $\begin{array}{l}\text { worldwide } \\
\text { scientists, } \\
\text { (Nobel Prize } \\
\text { winners) }\end{array}$ & $\begin{array}{l}\text { attracting } \\
\text { and retaining } \\
\text { international } \\
\text { talent }\end{array}$ & $\begin{array}{l}\text { attracting } \\
\text { and retaining } \\
\text { international } \\
\text { talent }\end{array}$ \\
\hline Faculty Student & 100 & 100 & 99.9 & 57.4 \\
\hline International Faculty & 99.4 & 99.8 & 91.6 & 89.6 \\
\hline $\begin{array}{l}\text { Hosting world events } \\
\text { (conferences, workshops, } \\
\text { etc.) }\end{array}$ & $\begin{array}{l}\text { major } \\
\text { world event } \\
\text { location }\end{array}$ & $\begin{array}{l}\text { major world } \\
\text { and regional }\end{array}$ & $\begin{array}{l}\text { regional and } \\
\text { national } \\
\text { reputation is } \\
\text { strong }\end{array}$ & $\begin{array}{l}\text { regional and } \\
\text { national } \\
\text { reputation is } \\
\text { strong }\end{array}$ \\
\hline
\end{tabular}

At the same time, Medicon Valley with its two major universities, Lund University and University of Copenhagen, and over 15 smaller life-science institutions - is a relatively younger ecosystem, which nevertheless has a stable generation of spin-offs and startups. The cluster is especially active in the research and studying of the fields of diabetes and neuroscientific research. Both universities are actively involved in attracting international faculty and students, with Lund University being more popular and thus more advanced in these efforts. In comparison to Cambridge University and Stanford University, Copenhagen and Lund universities have much lower feedback from employers mentioning university education as a driver of competence and innovativeness among graduates (Employer Reputation). Moreover, the two leading Medicon Valley universities stand lower in terms of the total number of citations received by all papers produced across a five-year period by their faculty members (Citations per Faculty), and, consequently, a smaller share of key innovations globally. Finally, Cambridge and Stanford Universities are 
more often hosting worldwide events (conferences, workshops, etc.), whereas Medicon Valley has a strong regional and national reputation for such events.

Considering the importance of universities in spatial, social, cultural and technologically mediated knowledge spillovers, this section discusses the interview survey findings on the role university-based innovation ecosystems play in the dissemination of scientific and technological knowledge via formal and informal social networks. Moreover, in university-based innovation ecosystems, formal relationships among organizations and their actors merge with personal networks. As Krugman (1991) points outs "knowledge flows are invisible". Thus, identification of the boundaries of knowledge flows within a particular personal network seems to be even more challenging. Therefore, the true value added of the following study resides in tracking the role of interactions at the human level not only at the organizational one.

The section below contains a summary of the most important questionnaire findings on the role each type of proximities played in each ecosystem (some original statements of the respondents are written in a cursive format). The significance of each type of proximities for socialdriven networking activities as a percentage share of the total responses is presented in Table 3.

\section{Geographical proximity}

"Close physical (walking) distance to both academic spin-offs and mature companies operating within the analyzed life-science" university-based innovation ecosystems, was mentioned as a very important driver of potential innovations by all the interviewed respondents (regardless of their work position). This is especially advantageous in terms of the "access to the latest knowledge spillovers via job mobility and organization of different academic, scientific events and research collaboration". More importantly, the role of physical interactions was placed above ICT and social media technologies of communications. Furthermore, Stanford University ecosystem representatives (university faculty and business managers) considered physical proximity as equally important for both formal and informal social networks. In this context, the interviewees from the Stanford and Cambridge University ecosystems emphasized the importance of "social infrastructure - sport centers, clubs, bars and coffees - that create opportunities for informal interactions". "Having a brief chat over a cup of tea or coffee" was an especially popular attitude for the respondents of the Cambridge University ecosystem. This is in contrast to the Copenhagen and Lund Universities life-science cluster representatives, who found "geographical proximity being less significant for the informal interactions". The latter confirms that 
geographical proximity alone is not sufficient to explain the process of how innovations happen within the ecosystems.

Table 3. Significance of each type of proximities for social-driven networking activities (in \%)

\begin{tabular}{lllll}
\hline Type of proximities & & Cambridge & Bay Area & Medicon Valley \\
\hline Geographical & yes & 100 & 100 & 80 \\
& no & - & - & 20 \\
Social & yes & 60 & 100 & 68 \\
& no & 5 & - & - \\
Organizational & yes & 85 & 92 & 80 \\
& no & - & - & - \\
Cognitive/ & yes & 96 & 75 & 82 \\
Technological & no & - & - & - \\
Institutional & yes & 65 & 70 & 62 \\
& no & - & - & - \\
Cultural & yes & 32 & 46 & 65 \\
& no & - & - & - \\
Source: own elaboration ("yes"-significant; “no"-not significant).
\end{tabular}

\section{Social proximity}

In terms of social proximity, the business-related respondents in the Bay Area pointed out that "social networking starts in the search of ideas but intensifies when selling technology or upgrading R\&D ideas" (closer to the maturity stage of their technologies). Yet, since the early or so called "idea search" stage is very often filled with certain precautions, they had also demonstrated the preoccupation to "do not say too much". In terms of academia, Cambridge University faculty emphasized the importance of "social relations and networking skills", however they also pointed out the potential problem of "putting too big a pressure on scientists to attend social events, as well as bridging and bonding efforts". As it was put by one faculty member "this may infringe the privacy and risk of someone scooping one s ideas". In a similar way, digital forms of social networking, "can facilitate communication but can limit one's privacy as it leaves traces".

Moreover, all the respondents acknowledged the common behavioral components such as "trust, professionalism and openness as key for the social networks creation and connections to relevant stakeholders". However, the Bay Area representatives were driven by a greater level of trust and openness. The latter was more often strengthened via non-physical networks, such as 
virtual platforms, e.g. alumni social media: Facebook, Linkedln, e.g. faculty members often had their class Facebook group.

\section{Organizational proximity}

The primary motives for partners to start talking about research or academic collaborations were found in their cognitive and organizational proximities. Several respondents in the Bay Area mentioned social networking events in the field of life science, organized by their own company or intermediaries, as "strengthening their intra- and inter-organizational networks and thus organizational proximity". They also admitted that "informal social networking events stimulated inter-organizational knowledge sharing as well as improved their competences, capabilities and resources". Organizational proximity further strengthened the social networks between the Bay Area university department representatives. The latter occurred via naturally emerging formal and non-formal problem groups. Solano and Ohlone Colleges had platform groups focusing on education and career support for teachers in the field of STEM (science, technology, engineering and mathematics). The platform group takes their private initiatives to "meet informally at an academic researcher's home in order to further exchange ideas and experiences in training teachers".

Furthermore, job mobility was mentioned as an "important process of bridging and networking between the various organizations". Researchers in the Bay Area mentioned that staying with one organization for around 4-5 years was an optimal period for successful career and professional network development. This contrasted with the respondents from the Cambridge and Medicon Valley ecosystems, who demonstrated poor job mobility and preferred long-term or undefined work contracts. Some incentives for job mobility were mentioned by the Medicon Valley respondents. The latter is also because the Danish part of the Medicon Valley has relatively higher wages and greater job opportunities than the Swedish part. Furthermore, the respondents from the Medicon Valley emphasized that there is "no need for constant geographical and social proximities in order to build organizational proximity, but rather an active participation in the organized meetings and short visits".

\section{Cognitive and technological proximities}

As the survey outcome shows, distance in terms of a knowledge base is both an enabler and an obstacle for the knowledge and innovative networking activities among the mentioned respondents. All the business respondents emphasized "the important role of local universities and R\&D centers as 
an incredible opportunity for knowledge spillovers and innovative activity" and that staying within "close proximity to the best universities in the world enabled them to acquire a high competence when dealing with the latest technologies". In this sense, limited competence and poor absorptive capacities of other non-local actors made the successful research interaction harder. This was especially emphasized by both faculty and business respondents from the two European life-science clusters. These respondents found technological proximities to be a "major challenge when expanding innovation-driven social networks with partners from Poland or Hungary". To some (limited) extent the gap created by cognitive and technological distances was bridged by intermediaries (e.g. individual faculty members, TTOs), institutional and cultural proximities.

In general, the respondents agreed with the importance of diversity, heterogeneity, and complementarity in enriching the capabilities and knowledge of actors involved in the innovation processes. Yet, Cambridge and Medicon Valley faculty and business respondents pointed out that "advancing from the same well established knowledge base and knowledge networks creates more opportunities", whereas Bay Area respondents emphasized the "importance of staying open and showing up at different regional and international life-science events is equally important - one never knows where the idea may come from".

\section{Institutional proximity}

In the view of $2 / 3$ of respondents in the selected sample "the ongoing technological convergence, enforces close collaboration between representatives of diverse knowledge bases within their local universitybased innovation ecosystems". The respondents from Medicon Valley and Bay Area universities admitted that "being institutionally proximate facilitates knowledge transfer and research collaboration". They also pointed out the "important role of TTOs and other intermediary-networking agents and institutions facilitating social networking and collaboration between various actors within their ecosystems". Moreover, once an established network of formal relationships among Triple Helix organizations merges with the informal social networks, the institutional proximity becomes less important. Thus, the respondents agreed that "intermediaries and institutional proximities play an essential role in narrowing social distances". Institutional proximity doesn 't seem to affect knowledge transfer much in the other two university-based innovation ecosystems. 
In terms of student-teacher relationship, the Bay Area university-based ecosystem has also a more open and direct attitude in comparison to the other university-based innovation ecosystems. To support this argument, one of the respondents provided an example of "a group of European visiting students at Stanford, who were considering asking a faculty member to organize a meeting with Nobel Prize winners, being afraid that the winners may not respond to their direct request. To their surprise the Nobel Prize winners not only answered but also showed their interest to come and meet them". Another example is the establishment of the Stanford Entrepreneurship Network (SEN) - a working group of faculty and student organizations - offering opportunities to gain entrepreneurial knowledge/ experience via advice, mentoring, and networking opportunities.

\section{Cultural proximity}

With regards to cultural proximity, nearly $1 / 2$ of all the respondents emphasized that "shared cultural, religious and linguistic backgrounds are very appreciated but not a precondition for successful social ties and more frequent interactions". However, almost everybody in the three analyzed university-based innovation ecosystems mentioned "openness (in sharing ideas and meeting people) as essential for strong and long-lasting social networks". Moreover, in the view of the interviewed scientists, managers and administrators, such behavioral components as "trust, openness, professionalism and complementarity become key drivers behind the social relationships and knowledge flows within the analyzed ecosystems".

Furthermore, the respondents from the Bay Area mentioned that "cultural proximity, resulting in the same cultural norms, habits and values, enables one to build trust and thus a willingness to exchange information". For example, in the Bay Area, respondents with Polish, Chinese or Hindi cultural roots were involved also in their national-based networks within the American Polish, Chinese, and Hindi migrant communities. In their opinion, their "cultural backgrounds enabled them to establish and facilitate professional scientific and social relationships within their groups (e.g. The Polish Club of Engineers, The US-Poland Science and Technology Symposium, The US-Poland Innovation HUB, etc.). In the case of the Hindi community, the "social networks lead to more intense outsourcing linkages with their peer researchers" in India. Few respondents mentioned any cultural differences as a barrier for building social networks. As one of the respondents remarked, "it takes more effort to reach a bond or open up Chinese researchers having strong cultural backgrounds". On the other hand, the following the 
statement was made by another respondent, "the culture of collaboration and openness is secured if there is an alignment of interests". One of the ways to develop openness, collaboration and entrepreneurship among the researchers is to take students summer jobs in different fast food restaurants such as McDonalds, which, as emphasized by one the respondents in the Bay Area, "strengthens their social networking, problem solving and team work skills". In terms of social multimedia, the respondents agreed that it "may ease these interactions". Yet, further research is needed to identify whether cultural values take any precedence over personal characteristics and motives in determining behaviour in the virtual world.

\section{DISCUSSION}

The research survey conducted with the representatives of the three universitybased innovation ecosystems - Cambridge (UK), Medicon Valley (EU) and Bay Area (US) ecosystems - allowed the identification of differences and similarities in which different proximities effect their social networks structure.

The Cambridge University ecosystem is rooted in a mature, worldclass cluster in life sciences. It featured by more closed social networks with hierarchical structures. Moreover, the intensity of networks somewhat circulates around more powerful or higher status individuals - Deans and Heads of Departments - interconnecting the other actors in the ecosystem as well as holding control over the information that originates from other networking groups. This way, the closed hierarchical network structure (in the spirit of Coleman, 1988) provides the ecosystem actors with greater trust, which might be very important when deciding whether to exploit a research/ business idea or not.

Interactions with individuals, which do not originate from a local ecosystem, tend to occur at larger distances. In terms of future social networks, the respondents in the Cambridge ecosystem emphasized the need to further exploit the diversity within the local vertical networks rather than horizontal ones (between other university-based innovation ecosystems). Here, the research study results pointed to the importance of physical, social, and organizational proximities when accessing the complementary knowledge base, feedback and support from the other faculty members within the Cambridge ecosystem.

Medicon Valley is considered to be one of the strongest, mature lifescience clusters in Europe. Its development and co-operation in life sciences was given a major boost in 2000, thanks to the European Development Fund, 
with the opening of the Öresund Bridge, joining Denmark and Sweden's lifescience clusters together into one dense, innovative cluster.

This provides benefits both from a learning perspective and an exploitation of innovation perspective. In the last decade, many new partnerships have been formed by a mix of Danish-Swedish, public-private, academic-industry representatives, as both countries share quite similar cultures and institutions. Nevertheless, the existing differences in culture and language between Denmark and Sweden, affects their differences in social set-ups. The relationships between the researchers and colleagues at the cross-border firm and university levels are based on educational and professional backgrounds rather than personal friendships and territorially contained trust and understanding. As in the view of Granovetter (1973), one could say that social networks in the Medicon Valley are characterized by weaker ties but a greater openness as in the sense of Coleman (1988). For this life-science ecosystem, physical proximity remains a necessary condition for the social proximity to evolve and sustain.

Finally, the high physical, technological, organizational and cultural (in its entrepreneurial spirit) proximities between the life-science ecosystem actors in the Bay Area intensifies their social relations and the interchange of ideas. The Bay Area life-science ecosystem is characterized by a diverse and open culture, in which personal contacts have great value. This creates a model rooted in the open innovation paradigm, collaborative workspaces and horizontal structures. It recombines features of both social network models - a closed one (Coleman, 1988) and a network one rich in structural holes (Burt, 1992). In this way, the life-science ecosystem in the Bay Area is similar to the IT sector in Silicon Valley (even though the locations of both clusters do not entirely overlap, with first being located more in San Francisco and the East Bay, and second in Santa Clara and Sunnyvale). Furthermore, as the study shows, the social networks within the Bay Area actors are characterized by strong social ties and are expanded via both vertical and horizontal integration within the life-science cluster. The latter promotes further firms' specialization in life science while enriching it with new emerging research and commercialization opportunities.

\section{CONCLUSION}

Despite different origins and founding models of the three analyzed university-based innovation ecosystems, the study reveals that they display similar patterns of inter- relationships between different types of proximities and social network configurations that sustain regional innovation activity. 
All of the levels of proximities have an important role to play in universitybased innovation ecosystems. They moderate the nature and dynamics of interactions among ecosystem actors, both via formal and informal relationships. Geographical proximity (the physical distance among actors) allows ecosystem players to have interactions that are more informal and serves as a pre-condition to strengthen social ties. On the other hand, the geographic proximity can really matter when strong social networks already exist. Subsequently, physical proximity enhances and strengthens personal relationships within the existing networks.

Furthermore, the primary motives for partners to start collaborations are to be found in their cognitive and organizational proximities. Thus, in order to strengthen social network ties within the life-science universitybased innovation ecosystems, organizational, technological and cognitive proximities within each ecosystem actor must be strengthened. The latter has important policy implications in which governments and local intermediary institutions can promote initiatives narrowing these proximities. The overall research findings showed that the communication dimension of proximity (even though it hasn't been considered as a separate type of proximity in the survey) is very important. In fact, analyzing the opinions of respondents, it is noticeable that communication and 'social proximity' is mutually reinforcing. Communication, through its wide array of workshops and events, enables socialization, whereas higher social proximity induces communication that is more frequent and the development of closer relationships.

The study identifies several fundamental relationships that determine the role of proximity within the university-driven social networks in the life-science ecosystems: (1) the presence of high physical, technological/ cognitive and organizational proximities within university-based ecosystems contribute to social networking and the interchange of knowledge and ideas; (2) cognitive and organizational proximities are the primary motives for social collaborations within university-based ecosystems; (3) physical proximity matters most when strong social networks already exist; (4) physical proximity allows ecosystem players to have interactions that are more informal; (5) cultural and social proximities (a common language, friendships and entrepreneurial spirit) increase more effective communication, trust and knowledge sharing; (6) social networking within university-based innovation ecosystems may be partially engineered by the brokerage function of intermediary organizations and managers, aiming to narrow organizational, technological and cognitive proximities between ecosystem players.

Although the results of the study are somewhat consistent with the findings of other researchers, Boschma's (2005) studies on social networks in a location specific context, as well as Porter's role of clusters in the localized 
knowledge spillovers, have a largely exploratory nature. Future studies would need to adjust the current research findings with the life-science industry`s technological dynamics. This is because the life-science industry goes through technological maturity in some fields and considerable growth in the others. Industries at different phases of their life cycle need different externalities to generate innovations. Therefore, it is important to carry out further tests on the role of different types of proximities in the case of the selected life-science industries specified environments. Apart from the types of proximities analyzed in the study, other factors may affect social ties within the life-science ecosystem, such as local actors absorptive and knowledge transfer capacities, which, on the other hand, may be determined by their talents and previous innovations.

The lack of in-depth consideration of the communication dimension of proximity is considered an important limitation of this study. Future research on the role of proximity within university-based innovation ecosystems must be enriched with communication aspects, which would enable the identification of what types, channels and formats of communication are most effective in bringing different ecosystem actors together and facilitating knowledge transfer between them.

Last, but not least, the increasing technological convergence and overall globalization of the life-science sector, challenges the ways in which the life-science university-based innovation ecosystems operate. Cross-region collaborations and international partnerships became of the key drivers of the life-science university-based innovation ecosystems growth. Further research on the role of proximity in moderating the nature and dynamics of interactions within the life-science university-based innovation ecosystems must consider increasing technological convergence and the overall globalization process within the life-science sector.

\section{Acknowledgments}

This research was funded by the OPUS grant (UMO-2016/21/BHS4/02008) by the Polish Science Centre: Social capital, innovativeness and growth of regions. Comparative analysis of biotechnology industry clusters. The author would like to thank all the interviewees from the following organizations for their openness and their time: Cambridge Enterprise Limited, Academic Alliances, Cambridge Networks; Copenhagen Capacity, Biopeople, Medicon Valley Alliance, Invest In Skane; Biocom, Women in Bio, Polish-Innovation Hub in Silicon Valley, Biomedical Manufacturing Network; AstraZeneca, Medimmune, MultiHelix AB, AstraZeneca, Medimmune, Babraham Bioscience Technologies; Numedii; Unnatural Products Inc.; Ingenium Waste 
in green; Twoporeguys; TermoFisher Scientific; BioSurplus; 2D Genomics; Scientists, lab researchers and faculty members: University of Copenhagen, Copenhagen Bio Science Park Labs, Cambridge University, Trinity College; Cambridge School of Clinical Medicine, Addenbrooke's Hospital; Stanford University, Clinical Excellence Research Center; Stanford University; Ohlone College; Ohlone College, Newark Campus, Stanford University, STEM education: California State University, East Bay, Naval Postgraduate School, Stamford University, Stanford University Technology Transfer.

\section{References}

Adams, R. (2002). Social Policy For Social Work. Basingstoke: Palgrave. http://dx.doi.org/10.1007/978-0-230-80178-3

Adler, P.S., \& Kwon, S.W. (2000). Social capital: Prospects for a new concept. The Academy of Management Review, 27, 17-40. http://dx.doi. org $/ 10.2307 / 4134367$

Antonelli, C. (2000). Collective knowledge communication and innovation: The evidence of technological districts. Regional Studies, 34, 535-547. http://dx.doi.org/10.1080/00343400050085657

Anselin, L., Acs, Z., \& Varga, A. (1997). Entrepreneurship, geographic spillovers and university research: A spatial econometric approach. Journal of Urban Economics, 42, 422-448. https://doi.org/10.1006/juec.1997.2032 Audretsch, D.B., \& Stephan, P.E. (1996). Company-scientist locational links: The case of biotechnology. The American Economic Review, 86, 641-652. 10.4236/ojpm.2011.13012

Audretsch, D.B., \& Feldman, M.P. (2004). Knowledge spillovers and the geography of innovation. Handbook of Regional and Urban Economics, 4, 13-39. https://doi.org/10.1016/S1574-0080(04)80018-X

Autio, E., \& Thomas, L. (2014). Innovation ecosystems: Implications for innovation. In M. Dodgson,D. Gann, N. \& Phillips (Eds.), The Oxford Handbook of Innovation Management. Oxford: Oxford Handbooks. http://dx.doi.org/10.1093/oxfordhb/9780199694945.013.012

Bania, N., Eberts, R., \& Fogarty, M. (1993). Universities and the startup of new companies: Can we generalize from Route 128 and Silicon Valley? The Review of Economics and Statistics. 75, 761-766. https://doi. org $/ 10.2307 / 2110037$

Burt, R.S. (1992). Structural Holes: The Social Structure of Competition. Cambridge, MA: Harvard University Press. http://dx.doi. org/10.4324/9780429494468-63

Baptista, R. (2001). Geographical clusters and innovation diffusion. Technological Forecasting and Social Change, 66(1), 31-46. http://dx.doi. org/10.1016/S0040-1625(99)00057-8 
Broekel, T. \& Boschma, R. (2016). The cognitive and geographical structure of knowledge links and how they influence firms' innovation performance. Regional Statistics, 6(2), 3-26. https://doi.org/10.15196/RS06201

Boschma, R. (2005). Proximity and innovation: A critical assessment. Regional Studies, 39(1), 61-74. https://doi.org/10.1080/0034340052000320887

Brockhoff, K., \& Teichert, T. (1995). Cooperative R\&D and partners' measures of success International. International Journal of Technology Management, 10(1),111-123. https://doi.org/10.1504/IJTM.1995.025617

Caniëls, M., Kronenberg, K., \& Werker, C. (2014). Conceptualizing proximity in research collaborations between universities and firms. In R. Rutten, P.Benneworth, D.Irawati,\& F. Boekema (Eds.), The Social Dynamics of Innovation Networks, Oxon: Routledge.

Carayannis, E., \& Campbell, D. (2012). Triple helix, quadruple helix and quintuple helix and how do knowledge, innovation and the environment relate to each other?. International Journal of Social Ecology and Sustainable Development, 1(1), 41-69. https://doi.org/10.1186/2192-5372-1-2

Chapple, W., Lockett, A., Siegel, D. S., \& Wright, M. (2005). Assessing the relative performance of U.K. University technology transfer offices: Parametric and non-parametric evidence. Research Policy, 3(34), 369-384. https://doi. org/10.1016/j.respol.2005.01.007

Christensen, T., Lämmer-Gamp, G., \& Köcker, M. (2012). Let's make a perfect cluster policy and cluster programme. Berlin/Copenhagen: The Danish Ministry of Science Innovation and Higher Education. Retrived from https://vdivde-it.de/system/files/pdfs/lets-make-a-perfect-clusterpolicy-and-cluster-programme.pdf

Coleman, J. (1988). Social capital in the creation of human capital. American Journal of Sociology. 94, 95-120. http://dx.doi.org/10.1086/228943.

European Commission. (2015). Open Innovation 2.0 Yearbook 2015. Retrieved from https://ec.europa.eu/digital-single-market/en/news/ open-innovation-publications

Etzkowitz, H. (2008). The Triple Helix: University-IndustryGovernment Innovation In Action. London: Routledge. https://doi. org/10.4324/9780203929605

Etzkowitz, H. (2003). Innovation in innovation: The triple helix of universityindustry-government relations. Journal of Social Science Information, 42(3), 293-337. https://doi.org/10.1177/05390184030423002

Etzkowitz, H., Mello, J.M.C., \& Almeida, M. (2005). Towards "metainnovation" in Brazil: The evolution of the incubator and the emergence of a triple helix. Research Policy, 34, 411-424. https://doi.org/10.1016/j. respol.2005.01.011

Feldman, M. (1999). The new economics of innovation, spillovers and agglomeration: A review of empirical studies. Economics of Innovation and New Technology, 8, 5-25. https://doi.org/10.1080/10438599900000002 
Etzkowitz, H., \& Leydesdorff, L. (1998). The endless transition: A "triple helix" of university industry-government relations. Minerva, 36, 203-208. https://doi.org/10.1023/A:1004348123030

Etzkowitz, H., \& Leydesdorff, L. (1995). The triple helix: university - industry - government relations: A laboratory for knowledge-based economic development. EASST Review, 14, 14-19. Retrieved from https://ssrn. com/abstract $=2480085$

Etzkowitz, H., \& Leydesdorff, L. (2000). The dynamics of innovation: From national systems and "Mode 2" to a triple helix of university-industrygovernment relations. Research Policy, 29(2), 109-123. https://doi. org/10.1016/S0048-7333(99)00055-4

Fisher, J. C., \& Pry, R. (1971). A simple substitution model of technological change. Technological Forecasting and Social Change, 3, 75-88. https://doi.org/10.1016/S0040-1625(71)80005-7

Fitjar, R.D., Huber, F., \& Rodríguez-Pose, A. (2016). Not too close, not too far: testing the Goldilocks principle of 'optimal' distance in innovation networks.. Industry and Innovation, 23(6), 465-487. https://doi.org/10.1 080/13662716.2016.1184562

Fransman, M. (2018). Innovation Ecosystems: Increasing Competitiveness. Cambridge: Cambridge University Press. http://doi.org/10.1108459706

Huggins, R., Prokop, D., \& Thompson, P. (2019). Universities and open innovation: The determinants of network centrality. Journal of Technology Transfer, 15(03). https://doi.org/10.1007/s10961-019-09720-5

Johnston, A., \& Huggins, R. (2017). University-industry links and the determinants of their spatial scope: A study of the knowledge intensive business services sector. Regional Science, 96(2), 247-260. https://doi. org/10.1111/pirs.12185

McAdam, M., \& Debackere, K., (2018). Beyond 'triple helix' toward 'quadruple helix' models in regional innovation systems: Implications for theory and practice, Journal of R\&D Management, 48(1), 3-6. http://doi. org/10.1111/radm.12309

Garnsey, E., \& Heffernan, P. (2010). High-technology clustering through spin-out and attraction: The Cambridge case. Regional Studies, 8(39), 1127-1144. https://doi.org/10.1080/00343400500328289

Glaeser, E., Kallal, H., Scheinkman, J., \& Shleifer, A. (1992). Growth in cities. Journal ofPolitical Economy, 100, 1126-1152. https://doi. org/10.1086/261856

Golejewska, A. (2018). Innovativeness of enterprises in Poland in the regional context. Journal of Entrepreneurship, Management and Innovation, 14(1), 29-44. https://doi.org/10.7341/20181412

González-López, M., Dileo, I., \& Losurdo, F. (2014). University-industry collaboration in the European regional context: The cases of Galicia and Apulia Region. Journal of Entrepreneurship, Management and Innovation, 10(3), 57-88. https://doi.org/10.7341/20141033 
Gordon, I.R., \& McCann, P. (2000). Industrial clusters: Complexes, agglomeration and/or social networks?, Journal of Urban Studies, 37(3), 513-532. https://doi.org/10.1080/0042098002096

Granovetter, M. (1973). The strength of weak ties. American Journal of Sociology, 78, 1360-80. https://doi.org/10.1086/225469

Hughes, A., \& Kitson, M. (2012). Pathways to impact and the strategic role of universities: New evidence on the breadth and depth of university knowledge exchange in the UK and the factors constraining its development. Cambridge Journal of Economics, 36(3), 723-750. https:// doi.org/10.1093/cje/bes017

Kim, H. (2013). Statistical notes for clinical researchers: Assessing normal distribution (2) using skewness and kurtosis. Journal of Restorative Dentistry Endodontics, 38(1), 52-54. Retrieved from https://www.ncbi. nlm.nih.gov/pubmed/23495371

Kenney, M. (2000). Understanding Silicon Valley. The Anatomy of an Entrepreneurial Region. Stanford: Stanford University Press. http://doi. org/ 10.0804737347

Knoben, J., \& Oerlemans, L. A. G. (2006). Proximity and inter-organizational collaboration: A literature review. International Journal of Management Reviews, 8(2), 71-89. https://doi.org/10.1111/j.1468-2370.2006.00121

Krugman, P. (1991). Geography and Trade. Cambridge: MIT Press. https://doi. org/10.1016/1059-0560(92)90026-9

Jensen, C., \& Tragardh, B. (2004). Narrating the triple helix concept in "weak" regions: Lessons from Sweden. International Journal of Technology Management, 27, 513- 530. https://doi.org/10.1007/978-1-4419-6536-3_22

Lorenzen, M. (2007). Social capital and localised learning: Proximity and place in technological and institutional dynamics. Journal of Urban Studies, 44(4). https://doi.org/10.1080/00420980601184752

Maskell, P., \& Mallberg, P. (1999). The competitiveness of firms and regions. 'Ubiquitification' and importance of localised learning. European Urban and Regional Studies, 6, 9-25. https://doi. org/10.1177/096977649900600102

Monge, P., Rothman, L., Eisenberg, E., Miller, K., \& Kirste, K. (1985). The dynamics of organizational proximity. Management Science, 31, 11291141. http://doi.org/10.1287/mnsc.31.9.1129. Nahapiet, J., \& Ghoshal, S. (1998). Social capital, intellectual capital, and the organizational advantage. Academy of Management Review, 23(2), 242-66. https://doi. org/10.5465/amr.1998.533225

Nooteboom, B. (2000). Learning by interaction: Absorptive capacity, cognitive distance and governance. Journal of Management and Governance, 4, 1-12. http://doi.org/ 10.1023/A:1009941416749

Petruzzelli, A.M. (2011). The impact of technological relatedness, prior ties, and geographical distance on university-industry collaborations: A joint-patent analysis. Technovation, 31(7), 309-319. http://dx.doi. org/10.1016/j.technovation.2011.01.008 
Ponds, R., Van Oort, F. G., \& Frenken, K. (2007). The geographical and institutional proximity of research collaboration. Papers in Regional Science, 86, 423-443. https://doi.org/10.1111/j.1435-5957.2007.00126.x

Ponds, R., Oort, F., \& Frenken, K. (2009). Innovation, spillovers and universityindustry collaboration: An extended knowledge production function approach. Journal of Economic Geography, 10(2), 231-255. https://doi. org/10.1093/jeg/lbp036

QS World University Rankings. (2018). Retrieved from www.topuniversities. com/university-rankings/

Saad, M., \& Zawdie, G. (2011). Theory and Practice of Triple Helix Model in Developing Countries: Issues and Challenges. New York: Taylor \& Francis. https://doi.org/10.4324/9780203838211

Schiumi, G., \& Carlucci, D. (2018). Managing strategic partnerships with universities in innovation ecosystems: A research agenda. Journal of Open Innovation Technology, Market, and Complexity, 4(25). https://doi. org/10.3390/joitmc4030025

Tratjenberg, M., Henderson R., \& Jaffe, A. (1997). University versus corporate patents: A window on the basicness of invention. Economics of Innovation and New Technology, 5, 19-50. https://doi. org $/ 10.1080 / 10438599700000006$

Tortoriello, M. (2015). The social underpinnings of absorptive capacity: The moderating effects of structural holes on innovation generation based on external knowledge. Journal of Strategic Management, 36(4), 586-597. https://doi.org/10.1002/smj.2228

Evald, M., Klyver, K., \& Svendsen, S. (2006). The changing importance of the strength of ties throughout the entrepreneurial process. Journal of Enterprising Culture, 14, 1-26. https://doi.org/10.1142/ S0218495806000027

Utterback, J., \& Abernathy, W. (1975). A dynamic model of process and product innovation. Omega. 3(6), 639-656. https://doi.org/10.1016/03050483(75)90068-7

Vonortas, N. S. (2009). Innovation networks in industry. In F. Malerba, \& N. S. Vonortas (Eds.), Innovation Networks in Industry. Cheltenham: Edward Elgar. http://doi.org/10.1848448015

Werker, C., Ooms W., \& Caniëls C. J. (2016). Personal and related kinds of proximity driving collaborations: A multi-case study of Dutch nanotechnology researchers. SpringerPlus, 5(1751). https://doi. org/10.1186/s40064-016-3445-1

Ziemiański, P. (2018). The perception of an entrepreneur's structural, relational and cognitive social capital among young people in Poland - An exploratory study. Journal of Entrepreneurship, Management and Innovation, 14(1), 109-122. https://doi.org/10.7341/20181416 


\begin{abstract}
Abstrakt
W ciggu ostatniej dekady badania $w$ dziedzinie technologii $i$ innowacji posunęły się w kierunku rozwoju pojęcia „ekosystemu” innowacji. Takie podejście stało się szczególnie przydatne w zrozumieniu dynamiki zwiqzanej ze złożonym procesem inwencji i jego przełożeniem na innowację, która dalej rozprzestrzenia się w społeczeństwie. Koncepcja ekosystemu innowacji opiera się na założeniu, że innowacje i postęp technologiczny nie wynikajq z wynalazczych wysiłków jednej osoby, lecz raczej ze wspólnych wysiłków badawczych i interakcji społecznych. Artykuł stanowi wkład w powstajqca debatę na temat ekosystemów innowacji poprzez dostarczanie nowych informacji i wiedzy na temat struktury powiqzań społecznych w uniwersyteckich ekosystemach innowacji. W szczególności celem artykułu jest zbadanie roli różnych typów bliskości w budowaniu więzi społecznych w uniwersyteckich ekosystemach innowacji na przykładzie sektora nauk przyrodniczych i biotechnologii. Omawiane sq dwa główne problemy badawcze: 1) struktura i rodzaj sieci społecznych w otoczeniu wybranych uniwersytów oraz 2) rola bliskości - geograficznej, społecznej, poznawczej, technologicznej, instytucjonalnej i kulturowej - jako czynnika silniejszych więzi społecznych i częstszych interakcji. Autorka stosuje wywiad jakościowy i metody obserwacji bezpośredniej, które pozwalaja lepiej zrozumieć złożonq naturę tworzenia się powiqzań społecznych $w$ ramach ekosystemu uniwersyteckiego nauk przyrodniczych. Badanie obejmuje kilka wybranych ekosystemów uniwersyteckich nauk przyrodniczych w Unii Europejskiej i Stanach Zjednoczonych. Wyniki wywiadów, analiza dostępnej literatury przedmiotu oraz innych zebranych dowodów empirycznych, umożliwiajq opracowanie odpowiednich wniosków oraz implikacji dla polityki i dalszych badań.
\end{abstract}

Słowa kluczowe: bliskość, więzi społeczne, ekosystem innowacji, nauki przyrodnicze, uniwersytet

\title{
Biographical note
}

Prof. Małgorzata Runiewicz-Wardyn graduated from Masters and doctoral studies at Warsaw School of Economics. Since 2004, she has been a research worker and lecturer at the Kozminski University in Warsaw (lectured subjects: Microeconomics, Macroeconomics, International Competitiveness, International Economics, Technology Dynamics and Innovation Policies, Business Economics). Her main scientific and research interests include the factors and measures of international competitiveness of countries and regions; knowledge-based economy; innovation systems; industry clusters; regional innovation policies. She was a Postdoctoral Fellow at Harvard and Berkeley Universities. She is the author of eight monographs and over 40 other scientific publications; coordinator and co-author of six European Commission research projects on e-economy, e-Learning and knowledge economy. 


\section{Conflicts of interest}

The author declares no conflict of interest.

\section{Citation (APA Style)}

Runiewicz-Wardyn, M. (2020). The role proximity plays in university-driven social networks. The case of the US and EU life-science clusters. Journal of Entrepreneurship, Management and Innovation, 16(3), 167-196. https://doi. org/10.7341/20201636 